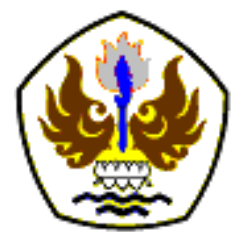

INFOMATEK

Volume 21 Nomor 1 Juni 2019

\title{
PERANCANGAN ULANG TATA LETAK FASILITAS PADA PT. STU DENGAN KRITERIA MINIMASI BIAYA
}

\author{
Hermita Dyah Puspita*), Ginanjar Abda'u \\ Jurusan Teknik Industri \\ Fakultas Teknik - Universitas Jenderal Achmad Yani
}

\begin{abstract}
Abstrak: PT. STU merupakan perusahaan pembuatan produk yang berbahan dasar logam. Kondisi tata letak saat ini pada lantai produksi perusahaan belum sesuai dengan aliran bahan, sehingga mengakibatkan terjadinya arus bolak-balik dan gerakan menyilang. Dengan adanya arus bolak-balik tersebut mengakibatkan jarak yang ditempuh selama proses produksi menjadi jauh, sebesar 125.424,8 meter dengan OMH (Ongkos Material Handling) sebesar Rp 104.851.262 pada periode Februari 2017 - Maret 2018. Permasalahan tersebut dapat diselesaikan dengan perancangan ulang tata letak awal yang disesuaikan dengan aliran bahan dengan menggunakan metode Systematic Layout Planning (SLP) ditambah dengan modifikasi berdasarkan batasan yang terdapat pada lantai produksi. Dari hasil perancangan terdapat 3 alternatif usulan tata letak yang terbentuk. Ketiga alternatif tersebut kemudian dievaluasi berdasarkan total jarak tempuh dan ongkos material handling. Dari hasil evaluasi didapatkan bahwa alternatif ke-3 memiliki total jarak tempuh dan $\mathrm{OMH}$ lebih kecil, sehingga alternatif ke-3 dipilih sebagai tata letak usulan. Hasil tata letak usulan ini memiliki aliran bahan yang lebih baik karena jarak tempuh yang diakibatkan oleh arus bolak-balik (back tracking) menjadi lebih pendek dan gerakan menyilang berkurang sebesar $58,82 \%$. Selain itu, total jarak tempuh yang terjadi pada tata letak usulan $43,05 \%$ lebih kecil, dan $\mathrm{OMH} 30,97 \%$ lebih kecil dibandingkan dengan tata letak awal.
\end{abstract}

Kata kunci: Systematic Layout Planning, Tata Letak Fasilitas, Minimasi Biaya

\section{PENDAHULUAN}

Metode penyusunan tata letak fasilitas pabrik semakin berkembang sejalan dengan semakin bertambahnya kompleksitas problem yang dihadapi di lantai produksi.

Salah satu hal penting yang merupakan kunci keberhasilan dari tata letak pabrik adalah jarak, waktu dan biaya (Handoko [1]). Jarak

\footnotetext{
") hermitadyah@gmail.com

Pertama diterima : 14 Mei 2019

Direvisi : 16 Mei 2019

Disetujui untuk publikasi: 20 Mei 2019
}

perpindahan material yang jauh menyebabkan waktu yang dibutuhkan untuk transportasi cukup tinggi, sehingga menyebabkan biaya yang dikeluarkan juga menjadi tinggi.

Kegiatan pemindahan bahan adalah kegiatan yang memerlukan biaya dan dapat mempengaruhi struktur biaya produksi (Kovács [2]), sehingga perlu dilakukan perencanaan, pengawasan, pengendalian dan perbaikan agar tujuan pemindahan bahan dapat tercapai (Apple [3]). Jika pola aliran 
material direncanakan dengan baik dan cermat akan mempunyai pemanfaatan ruang pabrik yang lebih baik, mengurangi waktu proses, meminimalkan kecelakaan kerja, aliran produksi menjadi lancar sehingga meningkatkan efisiensi produksi (Tompkins [4]). Perbaikan tata letak dan metode kerja dapat meningkatkan produktivitas (Risma dan Dian [5]). Tujuan dari tata letak adalah untuk mengurangi proses pemindahan bahan dan memudahkan pengawasan di dalam aktivitas produksi sehingga akhirnya terjadi penghematan (Wignyosoebroto [6]).

PT. STU merupakan perusahaan yang bergerak di bidang pembuatan produk yang berbahan dasar logam. Produk yang dihasilkan perusahaan yaitu alat-alat signaling kereta api, rangka generator, molding, dies, dan mesin tepat guna. Strategi respon terhadap permintaan yang digunakan oleh perusahaan adalah make to order dan engineer to order. Make to order digunakan untuk produk peralatan signaling kereta api, molding, dan dies. Perusahaan mulai produksi ketika terdapat pemesanan dari konsumen dan pemesanan disertai dengan desain gambar produk dari konsumen. Strategi engineer to order digunakan untuk produk mesin tepat guna. Pada strategi ini, perusahaan memulai produksi ketika terdapat pemesanan dari konsumen namun pemesanan tidak dengan desain gambar produknya, desain gambar dibuat oleh pihak perusahaan beserta spesifikasi dari produk tersebut. Walaupun engineer to order tapi pemesanannya repeat order dimana konsumen memesan kembali produk yang sama pada periode sebelumnya.

Alur produksi yang diterapkan oleh PT. STU adalah alur produksi berdasarkan proses (by process), dimana pengaturan dan penempatan mesin serta peralatan produksi ditempatkan ke dalam satu departemen yang memiliki fungsi yang sama (Matusek [7]).

Untuk menunjang tata letak tersebut dibutuhkan pengaturan dan penempatan tata letak yang baik. Pada saat ini lantai produksi PT. STU masih terdapat back tracking (arus bolak-balik) yang disebabkan oleh penempatan mesin yang belum sesuai dengan aliran bahan. Arus bolak balik ini menyebabkan bertambahnya jarak yang ditempuh sehingga $\mathrm{OMH}$ pun menjadi tinggi. Diantara beberapa macam produk yang dikerjakan oleh PT. STU, salah satu produk yang mempunyai jumlah pemesanan yang paling tinggi diantara produk yang lain adalah produk bezzel, sehingga dapat digunakan sebagai pedoman untuk mengatur tata letak di lantai produksi.

Dari Gambar 1 diagram alir proses pembuatan bezzel dapat dilihat bahwa kondisi tata letak 
saat ini menyebabkan terjadinya arus bolakbalik (back tracking) dan gerakan menyilang (cross movement). Arus bolak-balik terjadi sebanyak 2 kali dan gerakan menyilang terjadi sebanyak 17 kali. Adapun jarak yang ditempuh selama proses produksi pada bulan Februari 2017 - Maret 2018 adalah 128.458,34 meter dan ongkos material handling yang diperlukan sebesar $R p$ 107.160.605.

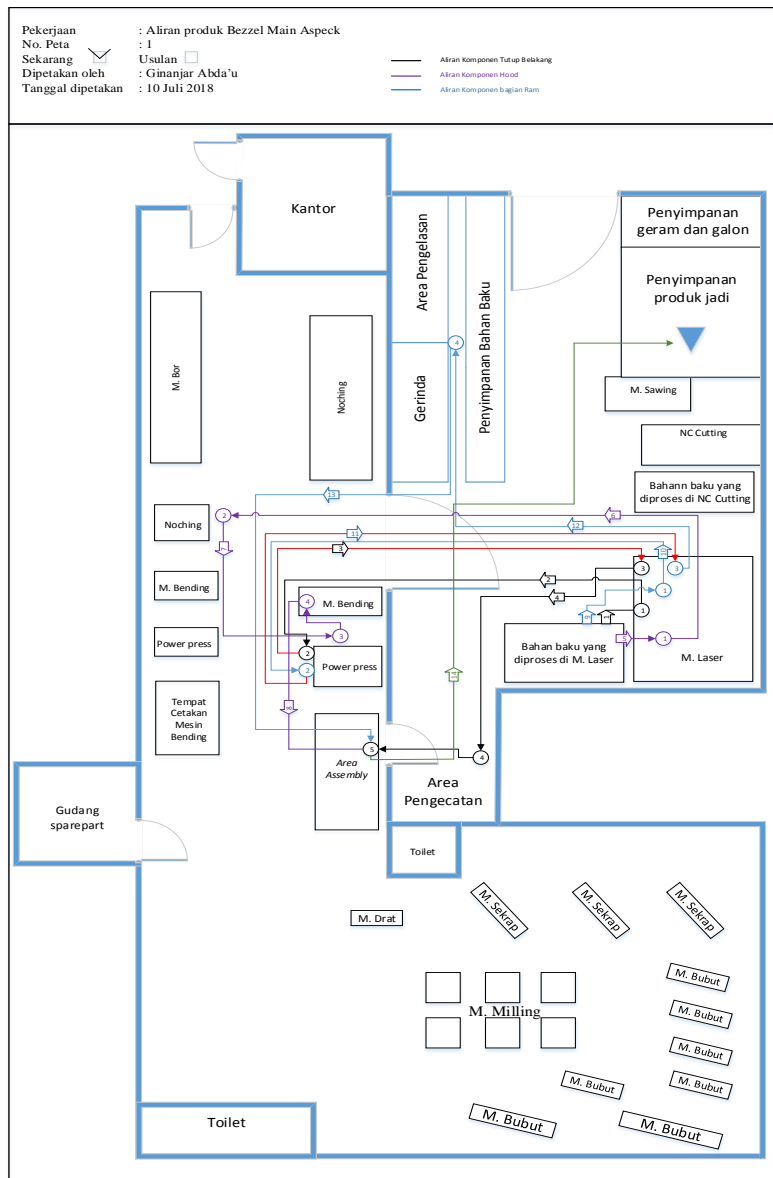

Gambar 1.

Diagram Alir Bezzel

\section{METODOLOGI}

\subsection{Studi Pendahuluan}

Langkah pertama yang dilakukan adalah studi pendahuluan. Studi pendahuluan merupakan studi yang dilakukan untuk memperoleh informasi tentang kondisi perusahaan saat ini yang berkaitan dengan penelitian yang akan dilakukan. Tahap ini dilakukan dengan cara observasi langsung ke perusahaan dan wawancara. Observasi dilakukan dengan cara pengamatan secara langsung kondisi yang ada di perusahaan dengan tujuan untuk mengetahui gejala atau fenomena yang dihadapi perusahaan. Studi pendahuluan yang telah dilakukan yaitu melihat jalannya proses produksi dari bahan baku sampai produk jadi dan yang berkaitan dengan tata letak fasilitas pabrik. Wawancara dilakukan dengan cara mewawancarai kepala produksi untuk mengetahui adanya keluhan yang dirasakan oleh operator dalam menjalankan proses produksi serta untuk mengetahui biaya material handling yang keluarkan oleh perusahaan.

Berdasarkan masalah yang ada yaitu kondisi tata letak fasilitas yang tidak sesuai dengan aliran bahan yang dapat mengakibatkan arus bolak-balik dan cross movement, maka perlu dilakukan perancangan ulang tata letak fasilitas agar sesuai dengan aliran bahan. 
Tujuan yang ingin dicapai dalam penelitian ini adalah merancang ulang tata letak fasilitas produksi yang memperlancar aliran produksi dan dapat meminimasi ongkos material handling.

\subsection{Identifikasi Data yang diperlukan}

Identifikasi data peneiltian yang dibutuhkan adalah sebagai berikut: 1. Deskripsi Produk, 2. Deskripsi Proses, 3. Jenis dan Jumlah Mesin, 4. Dimensi Mesin, 5. Layout Awal Perusahaan, 6. Data Alat Pemindahan Bahan.

\subsection{Metode Penelitian}

Metode yang digunakan dalam perancangan tata letak fasilitas menggunakan systematic layout planning (SLP). Metode SLP dikenalkan oleh Muther (1956) merupakan perancangan tata letak fasilitas produksi secara manual / konvensional (Muther [8]). SLP dipilih karena metode ini merancang layout dengan memperhatikan proses yang ada dan hubungan kedekatan masing-masing departemen berdasarkan aliran bahan serta dapat meminimasi ongkos material handling (Barnwal dkk. [9]), (Ojaghia dkk. [10]). SLP juga dapat meminimasi adanya arus bolak balik (back tracking) dan gerakan menyilang (cross movement) sehingga metode SLP digunakan sesuai dengan permasalahan yang sedang dihadapi perusahaan. Langkahlangkah dalam SPL dapat dilihat pada Gambar 2.

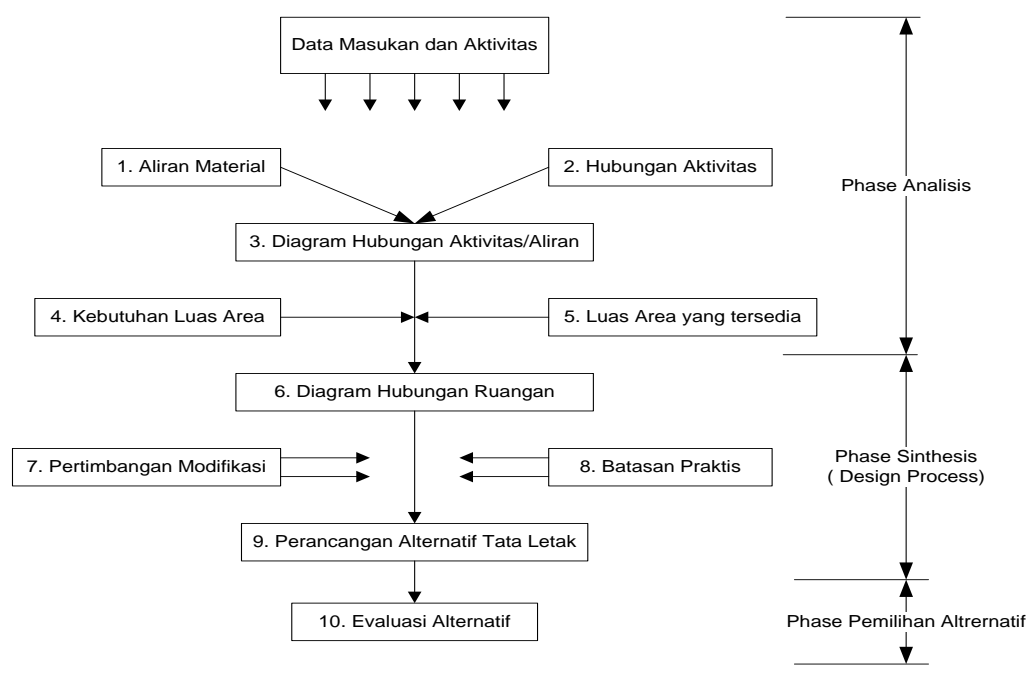

Gambar 2.

Langkah-langkah dalam SPL

Penjelasan Gambar 2:

1. Data Masukan dan Aktivitas
Pengumpulan data sebagai data masukan dalam penelitian ini dilakukan dengan melakukan survey secara langsung ke 
bagian engineering, bagian produksi, serta melakukan wawancara dan pengamatan terhadap pihak yang terlibat dalam proses produksi. Data masukan dan aktivitas dalam penelitian ini adalah: peta perakitan (assembly chart), bill of material (BOM), proses produksi mulai dari bahan baku yang dipakai untuk produk sampai menjadi produk jadi, peralatan dan mesin yang dibutuhkan, waktu yang dibutuhkan umtuk membuat produk.

2. Penentuan Aliran Material

Berdasarkan informasi data awal yang diperoleh maka tahap pertama yang dilakukan adalah menganalisa aliran material pada lantai produksi. Tahap ini dilakukan untuk mengetahui kondisi aliran material dan perpindahan material dari satu departemen ke departemen lainnya. Menggunakan from to chart table untuk mengetahui prioritas kedekatan antar fasilitas atau mesin secara kuantitatif dari segi biaya pemindahan material.

3. Penentuan Relationship Diagram

Activity Relationship Diagram merupakan suatu diagram hubungan antar aktivitas (mesin/ departemen) berdasarkan tingkat prioritas kedekatan, sehingga diharapkan ongkos material handling yang minimum (Rosyidi [11]). ARD dibuat berdasarkan prioritas pertama pada tabel skala prioritas, untuk kemudian diikuti dengan prioritas yang selanjutnnya. Bagian-bagian yang tidak masuk dalam prioritas boleh diletakkan berdekatan ataupun tidak, akan tetapi pada penempatannya tetap harus memperhitungkan bagian lain yang bisa jadi merupakan penghubung diantaranya.

4. Menghitung Kebutuhan Luas Area Langkah selanjutnya dalam aktivitas SLP adalah menentukan kebutuhan luas area untuk pengaturan segala fasilitas pabrik yang dibutuhkan. Pada tahap ini memperhatikan penempatan bahan, keleluasaan operator untuk bergerak dan kelonggaran (allowance). Perhitungan ini ditujukan untuk mengetahui luas area yang dibutuhkan tiap stasiun kerja yang ada di lantai produksi.

5. Luas Area Yang Tersedia

Pada penelitian ini luas area yang tersedia bisa didapat dengan mengukur kondisi tata letak fasilitas awal pada lantai produksi. Data luas area yang tersedia digunakan sebagai pembatas kebutuhan luas area pada proses perancangan ulang tata letak fasilitas.

6. Diagram Hubungan Ruang

Area Allocatoin Diagram (AAD) merupakan lanjutan dari $A R D$, dimana dalam ARD telah diketahui kesimpulan dari tingkat kedekatan antar departemen dengan demikian berarti bahwa ada sebagian departemen yang harus dekat dengan departemen yang lainnya dan ada juga sebaliknya, atau dapat dikatakan bahwa 
hubungan antar aktivitas mempengaruhi tingkat kedekatan antar tata letak aktivitas tersebut. Kedekatan tata letak aktivitas tersebut ditentukan dalam bentuk Area Allocation Diagram. Adapun dasar pertimbangan dalam prosedur pengalokasian area ini adalah ARD dan luas area yang dibutuhkan.

7. Pertimbangan Modifikasi Dan Batasan Praktis

Pertimbangan dan batasan praktis merupakan aspek yang dapat mempengaruhi rancangan tata letak fasilitas, meskipun berupa data kualitatif. Oleh sebab itu, pengamatan lebih jauh mengenai batasan praktis perlu dilakukan. Langkah ini dilakukan dengan menggali informasi dari lantai produksi.

8. Perancangan Alternatif Tata Letak

Perancangan tata letak bisa dibuat dengan cara mengkombinasikan pertimbanganpertimbangan kebutuhan luas area yang dibutuhkan. Kombinasi ini dapat dilakukan dengan membentuk AAD. Bentuk AAD merupakan desain alternatif tata letak dengan modifikasi seperlunya berdasarkan pertimbangan- pertimbangan yang diberikan. Kemudian dilakukan evaluasi Alternatif. Tahap ini merupakan tahap mengevaluasi alternatif-alternatif tata letak fasilitas yang akan diusulkan. Tahap ini bertujuan untuk memilih alternatif tata letak fasilitas terbaik. Langkah yang dilakukan dalam tahap ini yaitu menghitung dan membandingkan total jarak tempuh yang terjadi dan besarnya $\mathrm{OMH}$, sehingga dapat diperoleh alternatif terbaik yang memiliki total jarak tempuh dan biaya $\mathrm{OMH}$ yang paling minimum.

9. Alternatif Tata Letak Terbaik

Setelah didapatkan alternatif terbaik, selanjutnya dilakukan pembuatan template tata letak sesuai dengan AAD yang sudah dibuat.

\section{Perhitungan Feasibility Study}

Dari hasil alternatif terbaik kemudian dihitung feasibility study yaitu dengan menghitung biaya penjumlahan antara biaya intsalasi tata letak fasilitas baru dan biaya $\mathrm{OMH}$ tata letak fasilitas usulan, hasil dari penjumlahan biaya tersebut akan dibandingkan dengan $\mathrm{OMH}$ tata letak fasilitas perushaan saat ini. Hasil perbandingan tersebut untuk menunjukkan kelayakan dari perancangan tata letak fasilitas yang baru.

\section{ANALISIS DAN PEMBAHASAN}

Terdapat 16 jenis produk yang diproduksi pada periode Maret 2017 sampai dengan Februari 2018. Alat material handling yang digunakan untuk menunjang jalannya proses produksi yaitu hand pallet, hand Stacker, dan troli. Ketiga alat tersebut memiliki biaya alat pemindahan bahan sebesar, Rp 26.360.000, Rp 26.800.000, dan Rp 26.310.000. dan total 
jarak tempuh sebesar 3.077,4 meter, 521,1 meter, 43.590,3 meter serta manual operator sebesar 78.236 meter. Setelah itu dihitung $\mathrm{OMH}$ per meter tiap alat pemindahan bahan, hasil dari perhitungan tersebut adalah Hand Stacker sebesar Rp 51.429/ meter, Hand Pallet Rp 8.566/ meter, Troli Rp 604/ meter, dan Manual Operator Rp 331/ meter.

Perhitungan $\mathrm{OMH}$ dapat memberikan informasi berupa data total jarak tempuh yang terjadi dan total $\mathrm{OMH}$ awal dari proses produksi pada periode Maret 2017 - Februari 2018. Data-data tersebut digunakan untuk menggambarkan kondisi tata letak fasilitas awal dan sebagai kriteria uji pada penelitian ini. Proses produksi pada periode tersebut didapatkan total jarak tempuh yang terjadi sebesar 128.458,34 meter dan biaya $\mathrm{OMH}$ sebesar Rp 107.160.605.

\section{Langkah 1. Penentuan Aliran Material}

Tahap yang pertama dilakukan untuk melakukan perancangan tata letak fasilitas adalah menganalisis aliran material pada lantai produksi.

Peta kerja yang digunakan pada tahap ini adalah From to Chart. Tujuan menggunakan From to Chart adalah untuk mengetahui prioritas kedekatan antar fasilitas atau mesin secara kuantitatif dari segi biaya pemindahan bahan. Tabel 1. adalah From To Chart yang terbentuk.

Tabel 1. Tabel From To Chart

\begin{tabular}{|c|c|c|c|c|c|c|c|c|c|c|c|c|c|c|c|c|c|c|c|}
\hline From To & $\begin{array}{c}\text { Bahan } \\
\text { Valuu IC } \\
\text { Cutting }\end{array}$ & Gerinda & \begin{tabular}{|c|} 
Guldang \\
Bahan Baku
\end{tabular} & M. Bending & ML Bor & M. Bubut & MDrat & MG Gergaji & MLLas & M.Laser & MLVilling & MSekrap & NCCutting & Noching & Pengecatan & Perakitan & Porier Press & $\begin{array}{c}\text { Guldang } \\
\text { Produk Jadil }\end{array}$ & Total \\
\hline Bahan baku NC Cutting & . & & & & & & & & & & & & Rp27:077.369 & & & & & & Rp27.077.369 \\
\hline Gerinda & & . & & & & & & & & & Rp7.8019.913 & & & & & & & & Rp7.8019.913 \\
\hline Guldang Bahan Baku & & & . & & & & & & Rp97.279 & & & & & & & & & & Rp97.29 \\
\hline M. Bending & & Rpt.899 & & . & & & Rp1.283.486 & & Re28.746 & & & & & & $R p 00.577$ & & & & Rp1.367.707 \\
\hline MLBor & & & & Rpp14.829 & . & & & & Rp.0.17 & & Rpi38.955 & & & & Rp76.792 & Rpl13.557 & & & Rp556.150 \\
\hline M. Bubut & & & & Rpl.655.794 & Rp361.152 & . & & & Rp 198.72 & & Rp3877.768 & & & & Rp55.585.135 & Rpl.053.258 & & & Rpg.242.180 \\
\hline M.Drat & & & & & & & . & & & & & & & & Rpl13.864 & Rp5it,374 & & & Rpo682.33 \\
\hline MGergaji & & & & Rpp139.814 & Rp52430 & Rp5501.232 & & . & Rpp130.316 & & Rp394.264 & & & & & Rpt0.548 & & & Rpo6.258.604 \\
\hline MLas & & & & & & & & & . & & & & & & & Rp1.307.055 & & Rp67.8.869 & $\operatorname{Rp} 1.964 .924$ \\
\hline ML Laser & & & & Rp36.741 & & & & & Rp897.725 & . & & & & Rpl.1315.526 & Rpp87.018 & & Rp 7.529,720 & & Rp 10.656.730 \\
\hline MLVilling & & & & Rp268.818 & & & Rp23.170 & & Rp2.130701 & & . & & & & Rp3 3714,906 & Rp1.036.448 & & & Rp7.202013 \\
\hline MSekrap & & & & & & & & & & & Rp532.736 & - & & & & & & & Rp352736 \\
\hline ICCutting & & Rp22921.006 & & & Rp58.786 & & & & Rpl6.670 & & Rp2.382.854 & Rp7.760.192 & . & & & & Rp597.25 & & Rp 137736.743 \\
\hline Noching & & & & & Rp37.072 & & & & & & Rppl1.221 & & & . & & & Rp 797.842 & & Rp846.135 \\
\hline Pengecatan & & & & & & & & & Rpp172385 & & & & & & . & Rp1.040.995 & & Rpl5.105.288 & Rp16.318.668 \\
\hline Perakitan & & & & & & & & & & & & & & & & . & & Rpl.376.563 & Rppl.376.563 \\
\hline Porver Press & & & & Rp280.158 & & & & & Rpp483836 & & & & & & Rp864.109 & & . & & Rpl.628.103 \\
\hline Gudang Produk Jadi & & & & & & & & & & & & & & & & & & - & $\mathrm{RpO}$ \\
\hline Total & RpO & Rp2925:905 & $\mathrm{Rp} 0$ & Rp2.242.155 & Rpi50,740 & Rp5.501.232 & Rpl.306.656 & $\mathrm{RpO}$ & Rpt.163.48 & RpO & Rp11.639.711 & Rp.7.760.192 & Rp27.077.369 & Rpp.1.15.5.26 & Rpp11.282.399 & Rpj5.131.235 & Rpp8.924.798 & Rp17.139.720 & \\
\hline
\end{tabular}


Langkah 2. Penentuan Activity Relationship Diagram (ARD)

Gambar 3 adalah ARD yang terbentuk.

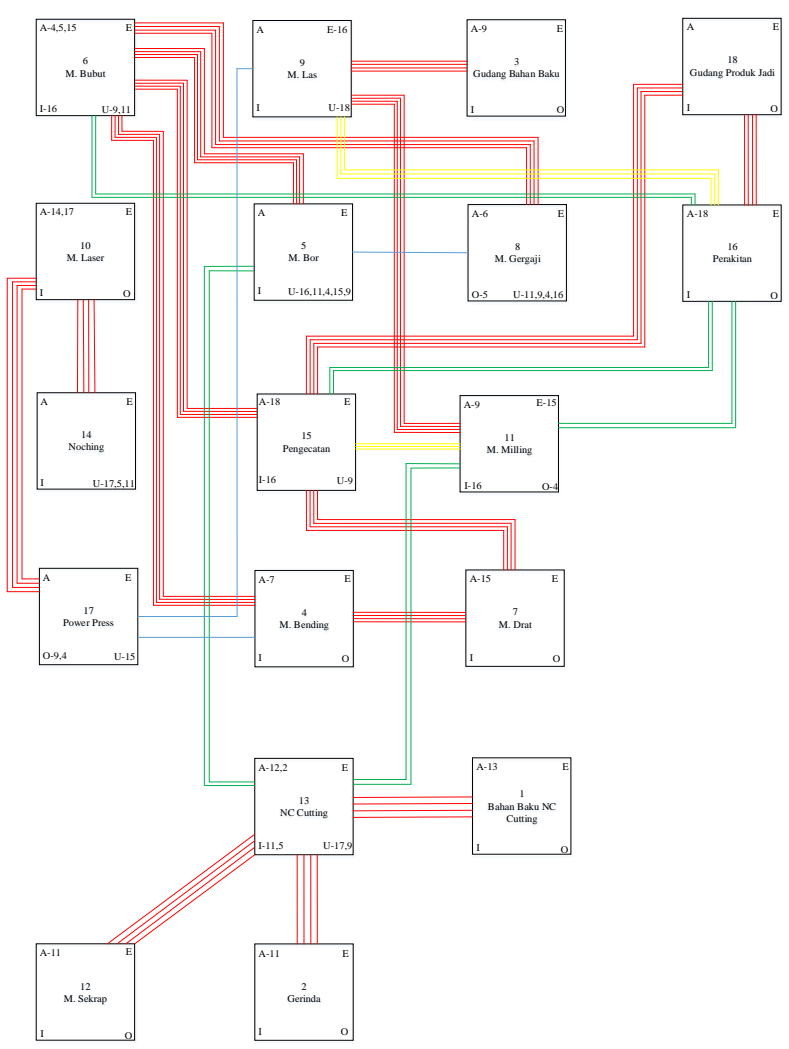

Gambar 3.

Activity Relationship Diagram

Langkah 3. Menghitung Kebutuhan Luas Area Pengaturan ruangan berkaitan erat dengan kebutuhan luas area yang dibutuhkan untunk fasilitas produksi atau mesin, penempatan bahan, keleluasan operator untuk bergerak dan kelonggaran. Perhitungan ini ditujukan untuk mengetahui luas area yang dibutukan untuk masing-masing fasilitas atau mesin yang terdapat dalam lantai produksi. Dari hasil perhitungan didapatkan kebutuhan luas area sebesar $265,5 \mathrm{~m}^{2}$

Tabel 2. Perhitungan Kebutuhan Luas Area

\begin{tabular}{|c|c|c|c|c|c|c|}
\hline \multirow{2}{*}{$\begin{array}{l}\text { Jenis Mesin } \\
\text { /Stasiun } \\
\text { Kerja }\end{array}$} & \multicolumn{2}{|c|}{ Ukuran (m) } & \multirow{2}{*}{$\begin{array}{l}\text { Luas } \\
\text { Mesin } \\
\left(M^{\wedge} 2\right)\end{array}$} & \multirow{2}{*}{$\begin{array}{l}\text { Allowance } \\
(100 \%)\end{array}$} & \multirow{2}{*}{$\begin{array}{l}\text { Jumlah } \\
\text { (unit) }\end{array}$} & \multirow{2}{*}{$\begin{array}{l}\text { Total } \\
\text { Luas } \\
\left(M^{\wedge} 2\right)\end{array}$} \\
\hline & $\mathbf{P}$ & $\mathbf{L}$ & & & & \\
\hline $\begin{array}{l}\text { Bahan baku } \\
\text { NC Cutting }\end{array}$ & 2 & 1,2 & 2,4 & 4,8 & 1 & 4,8 \\
\hline Gerinda & 2,5 & 2,4 & 6 & 12 & 20 & 12 \\
\hline $\begin{array}{l}\text { Gudang } \\
\text { Bahan Baku }\end{array}$ & 7,8 & 1,7 & 13,26 & 26,52 & 1 & 13,26 \\
\hline $\begin{array}{l}\text { Gudang } \\
\text { Produk Jadi }\end{array}$ & 6,1 & 4 & 24,4 & 48,8 & 1 & 24,4 \\
\hline \multirow{2}{*}{ M. Bending } & 1,8 & 0,6 & 1,08 & 2,16 & 1 & 2,16 \\
\hline & 3,7 & 1,2 & 4,44 & 8,88 & 1 & 8,88 \\
\hline M. Bor & 1 & 0,75 & 0,75 & 1,5 & 4 & 6 \\
\hline \multirow{3}{*}{ M. Bubut } & 2,1 & 0,6 & 1,26 & 2,52 & 5 & 12,6 \\
\hline & 3 & 0,6 & 1,8 & 3,6 & 1 & 3,6 \\
\hline & 3,6 & 0,6 & 2,16 & 4,32 & 1 & 4,32 \\
\hline M. Drat & 1,2 & 0,6 & 0,72 & 1,44 & 1 & 1,44 \\
\hline M. Gergaji & 1,2 & 0,6 & 0,72 & 1,44 & 3 & 4,32 \\
\hline M. Las & 2,5 & 2,4 & 6 & 12 & 10 & 12 \\
\hline M. Laser & 5,6 & 2,4 & 13,44 & 26,88 & 1 & 26,88 \\
\hline M. Milling & 1,5 & 1,5 & 2,25 & 4,5 & 6 & 27 \\
\hline M. Sekrap & 2,4 & 0,6 & 1,44 & 2,88 & 3 & 8,64 \\
\hline NC Cutting & 2,4 & 1,2 & 2,88 & 5,76 & 1 & 5,76 \\
\hline \multirow{2}{*}{ Noching } & 0,6 & 0,6 & 0,36 & 0,72 & 1 & 0,72 \\
\hline & 4 & 1 & 4 & 8 & 1 & 8 \\
\hline Pengecatan & 10 & 3 & 30 & 60 & 1 & 60 \\
\hline Perakitan & 2,4 & 1,2 & 2,88 & 5,76 & 2 & 11,52 \\
\hline \multirow{2}{*}{ Power Press } & 1,2 & 0,9 & 1,08 & 2,16 & 2 & 4,32 \\
\hline & 1,2 & 1,2 & 1,44 & 2,88 & 1 & 2,88 \\
\hline & & & & & Total & 265,5 \\
\hline
\end{tabular}

Langkah 4. Luas Area Yang Tersedia

Pada penelitian ini luas area yang tersedia bisa didapat dengan mengukur kondisi tata 
letak fasilitas awal pada lantai produksi perusahaan. Dengan mengetahui informasi mengenai luas area yang tersedia pada lantai produksi, maka dapat dilakukan perbandingan untuk mengetahui apakah luas area yang tersedia dapat memenuhi kebutuhan luas area produksi. Hal tersebut dapat dilihat pada tabel 3 berikut ini.

Tabel 3. Perbandingan Luas Area yang Dibutuhkan dan Luas Area yang Tersedia

\begin{tabular}{ll}
\hline Data & Luas $\left(\mathbf{m}^{\mathbf{2}}\right)$ \\
\hline Total Kebutuhan Luas Area & 265,5 \\
Secara Teoritis & 702,3 \\
Luas Area yang Tersedia & \\
\hline
\end{tabular}

Tabel 3 menunjukkan bahwa luas area yang tersedia pada lantai produksi dapat memenuhi kebutuhan luas area produksi yang dibutuhkan. Dengan kata lain, perancangan ulang tata letak fasilitas dapat dilakukan pada lantai produksi perusahaan tanpa harus melakukan penambahan luas area yang tersedia.

Langkah 5. Diagram Hubungan Ruang Pembentukan diagram hubungan ruang atau Area Alocation Diagram (AAD) dilakukan dengan menggambar ulang susunan fasilitas atau mesin pada diagram hubungan aktivitas (ARD). Fasilitas atau mesin yang digambar pada diagram ini masih berbentuk blok diagram, tetapi ukurannya sudah disesuaikan dengan ukuran yang sebenarnya dari hasil perhitungan luas area tiap fasilitas atau mesin.
Tujuan pembuatan ini adalah untuk dapat menyesuaikan posisi tiap fasilitas atau mesin dengan mempertimbangkan ukuran mesin dan luas area yang tersedia. Gambar 3 memperlihatkan area location diagram.

Langkah 6. Pertimbangan Modifikasi Dan Batasan Praktis

Pada proses perancangan tata letak fasilitas lantai produksi PT. STU terdapat hal-hal yang perlu dipertimbangkan. Hal-hal tersebut merupakan kondisi atau keadaan dari tata letak fasilitas awal dan tidak akan dirubah, sehingga perlu dilakukannya pertimbangan terhadap modifikasi yang akan dilakukan.

Adapun hal-hal yang perlu dipertimbangkan tersebut, yaitu :

1. Kondisi bangunan atau gedung lantai produksi hanya memiliki satu pintu untuk akses keluar dan masuk, sehingga perlu mempertimbangkan pola aliran bahan yang akan digunakan dalam perancangan tata letak fasilitas. Pola aliran yang sesuai dengan kondisi seperti ini adalah pola $U$ shape.

2. Area pengecatan tidak dapat dipindahkan karena area tersebut membutuhkan desain khusus untuk pengecatan, sehingga area pengecatan yang sudah ada akan tetap dijadikan area pengecatan untuk modifikasi tata letak yang akan dilakukan ke depannya. 


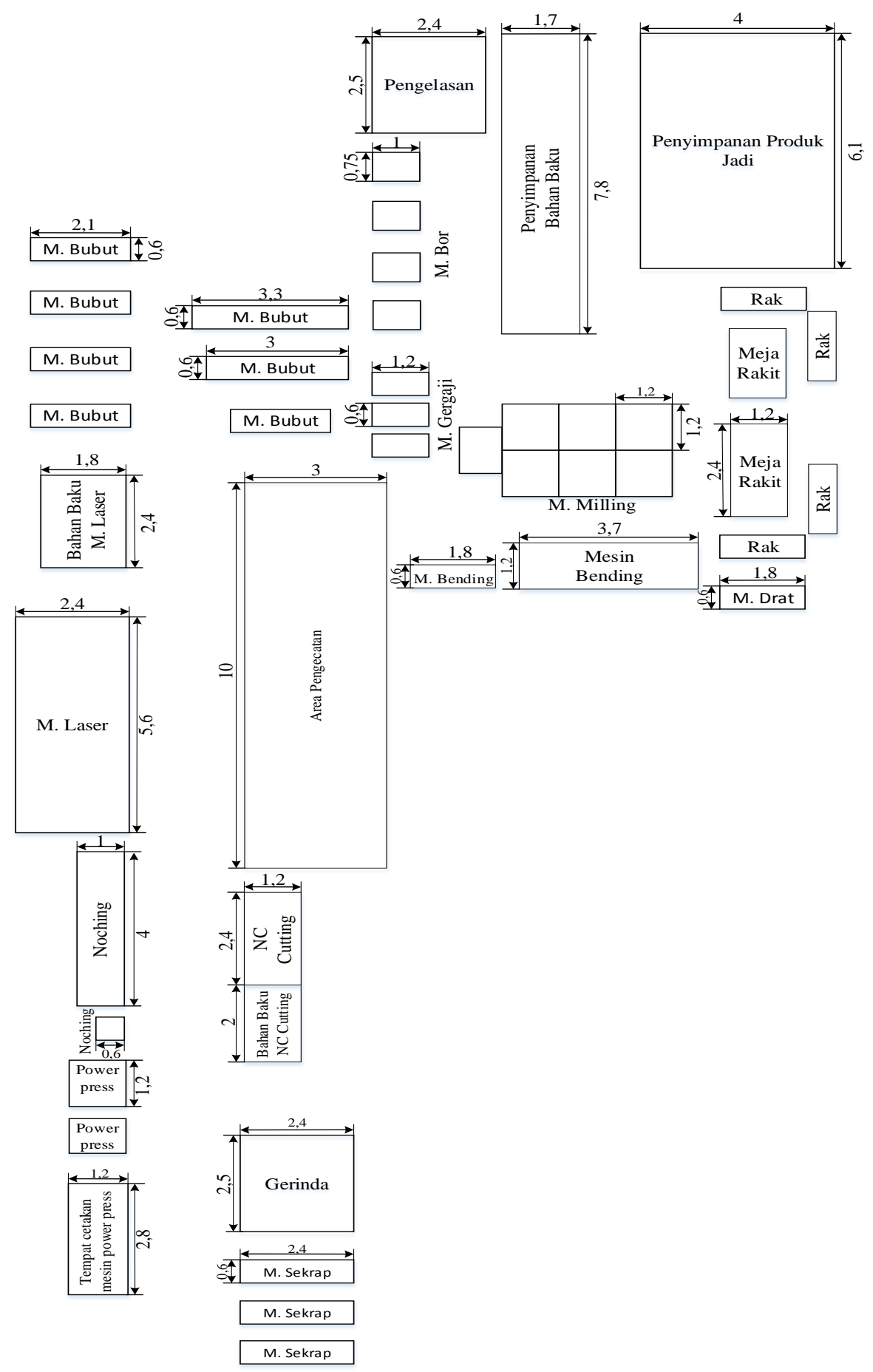

Gambar 4.

Area Alocation Diagram 
Dalam menentukan luas gang antar mesin, perlu mempertimbangkan ukuran dari alat pemindah bahan yang digunakan. Alat pemindahan bahan yang digunakan antara lain handstacker, handpallet, dan troli. Tujuannya adalah agar alat tersebut dapat bergerak secara leluasa.

Langkah 7. Perancangan Alternatif Tata Letak Pada tahap ini dilakukan perancangan alternatif tata letak dengan membuat alternatif
Area Alocation Diagram (AAD) beserta total jarak yang ditempuh.

\section{Langkah 8. Evaluasi Alternatif}

Evaluasi alternatif dari segi total jarak tempuh dan OMH.Hasil evaluasi perhitungan total jarak tempuh yang terjadi dan $\mathrm{OMH}$ dari ketiga alternatif tata letak fasilitas dapat dilihat pada Tabel 4.

Tabel 4 Rekapitulasi Hasil Evaluasi

\begin{tabular}{llcccc}
\hline No & \multicolumn{1}{c}{ Kriteria } & Tata Letak Awal & Alternatif 1 & Alternatif 2 & Alternatif 3 \\
\hline 1 & Total Jarak Tempuh yang Terjadi & $125.414,80$ meter & 76585,6 meter & 78832,4 meter & 71429,2 meter \\
\hline 2 & OMH & Rp104.851.262 & Rp77.886.468 & Rp74.140.065 & Rp72.378.568 \\
\hline 3 & Back Tracking & $2(80,6$ meter $)$ & $2(17,3$ meter $)$ & $2(21,7$ meter $)$ & $2(16,6$ meter $)$ \\
\hline 4 & Cross Movement & 17 & 4 & 6 & 7 \\
\hline
\end{tabular}

\section{Langkah 9. Alternatif Tata Letak Terbaik}

Berdasarkan hasil evaluasi alternatif, maka alternatif tata letak fasilitas terbaik adalah alternatif 3. Hal tersebut diputuskan karena alternatif 3 memiliki total jarak tempuh dan OMH yang paling rendah, yaitu $71.429,2$ meter dan Rp 72.378.568. Gambar 4 adalah tata letak alternatif 3 yang terpilih.

\section{Langkah 10. Perhitungan Feasibility Study} Perhitungan biaya perubahan tata letak usulan meliputi :

a. Biaya sewa forklift dan operator (2 hari) Biaya sewa forklift dan operator $=R p$ 1.500 .000 / hari
Biaya selama 2 hari $=R p 1.500 .000 \times 2=R p$ 3.000 .000

b. Biaya perubahan panel listrik ( 3 titik) Biaya pemasangan panel listrik $=R p 235.000 /$ titik

Biaya panel 3 titik $=R p 235.000 \times 3=R p$ 705.000

c. Biaya pembuatan pondasi untuk mesin Biaya pembuatan pondasi untuk mesin $=\mathrm{Rp}$ 500.000

Total biaya perubahan tata letak usulan 
= Biaya sewa forklift dan operator + Biaya perubahan panel listrik + Biaya pembuatan pondasi untuk mesin $+\mathrm{OMH}$ tata letak usulan $=R p 3.000 .000+R p 705.000+R p 500.000+$ Rp 72.378.568 $=\operatorname{Rp} 76.583 .568$
Jadi berdasarkan penjumlahan antara biaya instalasi tata letak fasilitas baru dan biaya $\mathrm{OMH}$ tata letak fasilitas usulan memiliki biaya yang lebih kecil dibanding biaya $\mathrm{OMH}$ tata letak fasilitas perusahaan saat ini, artinya proses perancangan tata letak baru dapat dilakukan atau layak diimplementasikan.

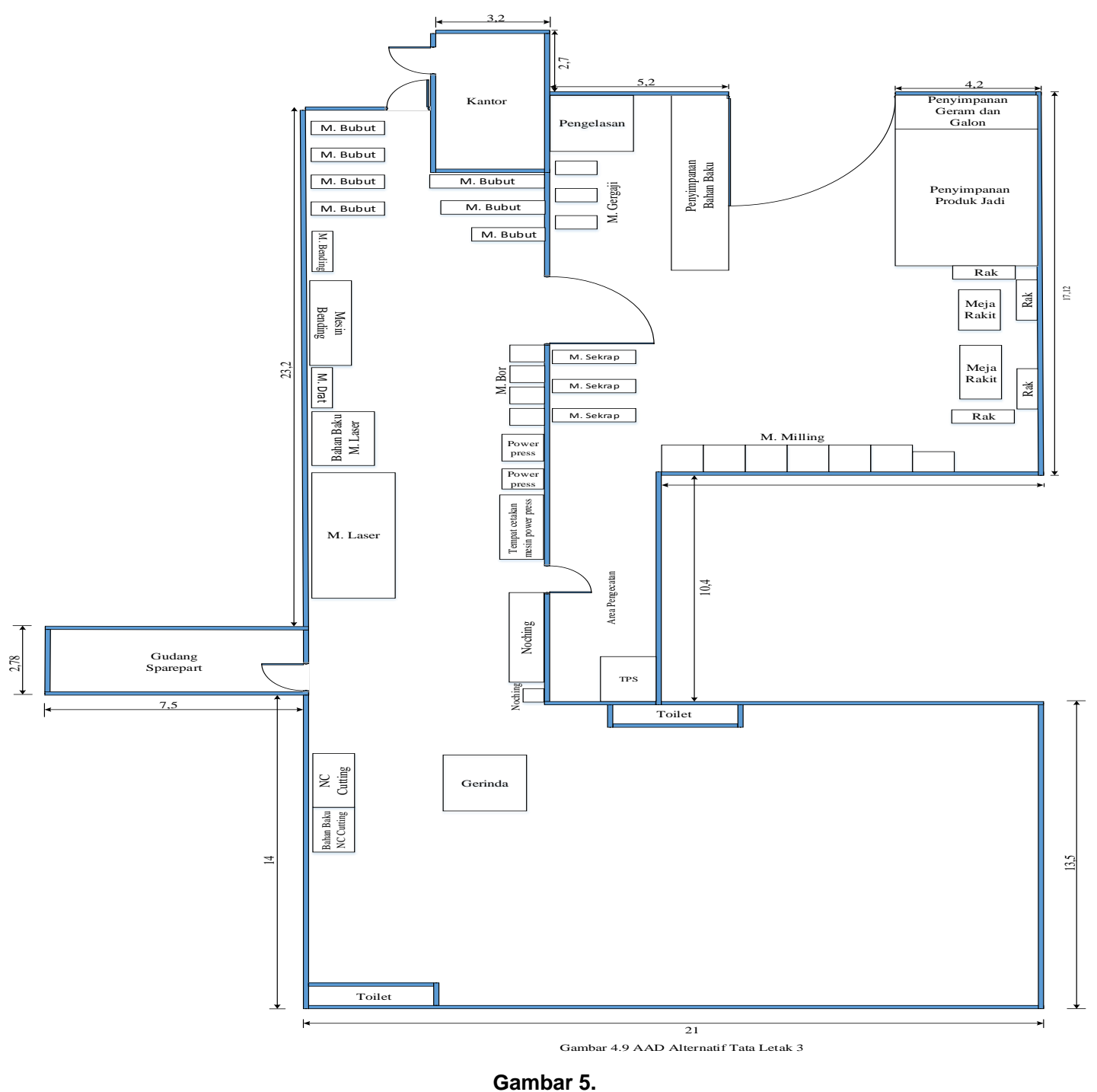

Tata Letak Alternatif 3 yang Terpilih 


\section{KESIMPULAN}

Berdasarkan penelitian yang dilakukan, maka dapat diambil kesimpulan sebagai berikut:

1. Hasil analisis diagram alir terhadap tata letak fasilitas usulan menunjukkan bahwa kegiatan arus bolak balik (back tracking) jaraknya berkurang, dan gerakan menyilang (cross movement) pun berkurang menjadi 7 gerakan.

2. Total jarak tempuh pada tata letak fasilitas usulan adalah sebesar 71.429,2 meter, total jarak tempuh pada tata letak fasilitas usulan 44,39\% lebih kecil dibandingkan tata letak fasilitas awal, yaitu sebesar 128.458,34 meter. Sedangkan $\mathrm{OMH}$ pada tata letak fasilitas usulan sebesar $\mathrm{Rp}$ 72.378.568. dengan persentase $32,45 \%$ lebih kecil dibandingkan tata letak fasilitas awal yaitu sebesar Rp 107.160.605.

3. Waktu kerja operator dan alat material handling lebih ringkas.

\section{DAFTAR PUSTAKA}

[1] Handoko, A. "Perancangan Tata Letak Fasilitas Produksi Pada UD AHENG Sugar Donut's di Tarakan". Calyptra Jurnal IImiah Mahasiswa Universitas Surabaya, vol 2, no. 2, pp. 1-21, 2013.

[2] Kovács, G, Kot, S. "Facility Layout Redesign for Efficiency Improvement and Cost Reduction". Journal of Applied Mathematics and Computational
Mechanics, vol 16, no. 1, pp. 63-74, 2017

[3] Apple, J. M. Tata Letak Pabrik dan Pemindahan Bahan. Edisi ketiga. Bandung: Institut Teknologi Bandung, 1990.

[4] Tompkins, J. A. Facilities Planning, Third Edition. New Jersey: John Wiley and Sons Inc., 2003.

[5] Risma A, S, Dian, H,. Usulan Perbaikan Metode Kerja Berdasarkan Micromotion Study Dan Penerapan Metode 5S Untuk Meningkatkan Produktifitas. Jurnal Teknologi, Institut \& Teknologi AKPRIND Yogyakarta, Volume. 1 No., pp. 191-203, 2008.

[6] Wignjosoebroto, S. Tata Letak Pabrik dan Pemindahan Bahan. Surabaya: Penerbit Guna Widya, 2009.

[7] Matusek, M. Layout Planning: A Case Study on Engineering-to-Order Company. Jeseník, Czech Republic: Carpathian Logistics Congress. 2012.

[8] Muther, R. Practical Plant Layout. New York: Mc Graw-Hill Book Company, 1956.

[9] Barnwal, S., Dharmadhikari. P. "Optimization of Plant Layout Using SLP Method". International Journal of Innovative Research in Science, Engineering and Technology, vol. 5, issue 3, pp. 3008-3015, 2016.

[10] Ojaghia, Y., K. Alireza, Yusofa, N.M., Renania, N.G., Hassana, S. A. H. S. 
Infomatek Volume 21 Nomor 1 Juni 2019 : 27 - 40

"Production Layout Optimization for Small

vol. 16, no. 01, pp. 82-95, 2018.

and Medium Scale Food Industry".

Procedia CIRP, vol. 26, pp 247 - 251, 2015.

[11] Rosyidi, M.R. "Analisa Tata Letak Fasilias

Produksi dengan Metode ARC, ARD, dan AAD di PT XYZ". Jurnal Teknik WAKTU, 